\title{
Choice of Law: A Fond Farewell to Comity and Public Policy
}

In the 1985 case of Wong v. Tenneco, Inc., ${ }^{1}$ the California Supreme Court invalidated a contract by applymg Mexican law despite the fact that both parties were California citizens and the contract had been made and perforned in California. In reaching its decision the court applied not the doctrine of governmental interest analysis, California's approach to choice of law questions for the last twenty years, but the older doctrine of comity of nations. ${ }^{2}$ In the same year two other state high courts reached choice-of-law decisions by using a nodern choice-of-law approach and then applying the older public policy exception to the comity doctrine. ${ }^{3}$ At one time comity and the public pohicy exception rationales governed choice-of-law decisions. ${ }^{4}$ In contrast to modern systematic approaches, however, the older doctrines lack both analytical structure and standards for determining when and how they should be applied. $^{5}$

The traditional lex loci choice-of-law rules, around which both comity and its public policy exception developed, have increasingly been replaced by inodern policy-oriented choice-of-law approaches. ${ }^{6}$ These 1985 cases, decided by each state's highest court in three different states adopting inodern approaches, present a strange and unexplained blend of old and new approaches to choice-of-law questions. They could be interpreted as signaling a retreat from their states' modern approaches. Certainly, they evidence a need to define the analytical relationship between modern choice-of-law approaches and the comity and public policy doctrines.

This Cominent explores the backgrounds of the comity and public policy doctrines, reviews the development of modern choice-of-law techniques, and evaluates the place of the comity and public policy doctrines against this inodern backdrop. This Comment argues that the criticisms of these doctrines as vague and lacking objective standards are well

1. 39 Cal. 3d 126, 702 P.2d 570, 216 Cal. Rptr. 412 (1985).

2. Id. at $135-38,702$ P.2d at 576-78, 216 Cal. Rptr. at $418-20$.

3. Schultz v. Boy Scouts of America, Iuc., 65 N.Y.2d 189, 480 N.E.2d 679, 491 N.Y.S.2d 90 (1985); Boardman v. United Services Auto. Ass'n, 470 So. 2d 1024 (Miss.), cert. denied, 106 S. Ct. 384 (1985).

4. See, e.g., Hilton v. Guyot, 159 U.S. 113 (1895).

5. See, e.g., Lilienthal v. Kaufman, 239 Or. 1, 13, 395 P.2d 543, 548 (1964) (difficulty of determining what is fundamental policy in the absence of objective standards).

6. See Kay, Theory into Practice: Choice of Law in the Courts, 34 Mercer L. Rev. 521 (1983). 
founded, that modern choice-of-law techniques arose primarily as an attempt to develop objective standards in place of the older doctrines, and that the values reflected in the comity and public policy doctrines are better served by more focused policy-oriented methods. Thus the old doctrines are superfluous in states adopting a modern approach. Indeed, most of those states have abandoned them. Moreover, though the modern approaches have themselves been criticized, a return to the doctrines of comity and public policy would not resolve their weaknesses. Since the doctrines of comity and public policy can no longer serve a useful purpose, they should be abandoned by modern courts and relegated to background studies of the evolution of choice-of-law doctrine in the Umited States.

I

\section{BACKGROUND LAW}

\section{A. Traditional Choice-of-Law Rules}

The concept of vested rights as a primary determinant in choice-oflaw decisions prevailed in the Uirited States during the early 1900's. ${ }^{7}$ The rules of vested rights were rigid and unyielding. Joseph Beale, a highly influential conflict-of-laws theorist during the early 1900's, developed the concept of "vested rights." Beale insisted that once a right is lawfully created in a given jurisdiction, it must be recognized and validated everywhere. ${ }^{8}$ Just as a foreign judgment or action in foreign territory creates a vested right, a foreign law creates a vested right. ${ }^{9}$

These rules trace their history back to Europe in the Middle Ages. Until the Middle Ages, courts generally applied lex fori, the law of the fornm adjudicating the case. With the rise of international cominercial relations, European nations saw the value of a more accommodating attitude toward foreigners as well as peaceable and just relations with other trading nations. It became important to recognize the law of the country in which the disputed acts had occurred. Thus, the rules of lex loci-the

7. E. SCOLES \& P. HAY, CoNFLICT OF LAWS $\S 2.5$ (Lawyer's Ed. 1984).

8. 3 J. BEALE, TREatise ON THE Conflict of LAWS app. § 73, at 1969 (1935); see Slater v. Mexican Nat'1 R.R., 194 U.S. 120, 126 (1904); Loucks v. Standard Oil, 224 N.Y. 99, 110-11, 120 N.E. $198,201-02$ (1918).

9. Beale codified the vested rights approach in the Restatement of Conflict of Laws (1934). In torts, for example, the rule was lex loci delicti: the law of the place where the last act occurred necessary to complete injury became the rule of decision in the case. $\S \S 377-78$. At death, the law of the situs governed disposition of real property, and the law of the domicile determined disposition of personal property. $\S \S 245,303,306$. The interpretation of contracts was governed by the law of the state where the contract was made and the performance of the contract by the law of the state where it was performed. $\S \S 332,358$. The rules for contracts were not nearly so well established, however, as those for torts and property. See, e.g., E. SCOLES and P. HAY, supra note 7, § 18.14 (discussing the difficulty of determining a single place of contracting). 
law of the place where the act occurred-developed. ${ }^{10}$

These rules developed at a time when most transactions were geographically limited, and transportation and communication were slow and cumbersome. Under the rules of lex loci a single factor located the event and thus the state whose law should be applied. ${ }^{11}$ The underlying assumption was that there is one significant event and an obvious single state, the locus of that event, with which both parties to the dispute had significant connections, and that state would thus have the strongest contacts with the dispute. Its law, therefore, would ordimarily be applied regardless of the forum adjudicating the dispute. ${ }^{12}$

During the early 1900's, however, this chain of assumptions began to break down. With the mcreased speed and frequency of modern transportation and communication, transactions increasingly transcended state borders and human activities became more complex and imterdependent. Today, it is common for more than one state to have a significant interest in a dispute, frequently rendering the location of the disputed act fortuitous. ${ }^{13}$ Consequently, the old vested rights rules im the modern age began to produce arbitrary and inappropriate results. ${ }^{14}$

\section{B. Comity and the Public Policy Exception}

Coinity as a choice-of-law mechanism in the United States is generally traced to the writings of Joseph Story in the early 1800's. ${ }^{15}$ Comity, he said, refers to the paramount obligation of nations or states to give effect to foreign laws when that foreign law is the appropriate law for the case. That obligation rests, however, not on any right possessed by another nation to require application of its law, but rather on the forum's

10. See Yntema, The Comity Doctrine, 65 Mich. L. REv. 9, 9-19 (1966) (discussing the evolution of lex loci).

11. Korn, The Choice-of-Law Revolution: A Critique, 83 Colum. L. REv. 772, 778 (1983).

12. See Dym v. Gordon, 16 N.Y.2d 120, 124, 209 N.E.2d 792, 794, 262 N.Y.S.2d 463, 466 (1965) (discussing the rationale for the old lex loci delicti rule, which New York had abandoned).

13. See Gutierrez v. Collins, 583 S.W.2d 312, 317 (Tex. 1979) (discussing the failings of lex loci, which leads to "arbitrary and unjust" results, and of the exceptions that developed, which undermined uniformity and led to an "unworkable, irrational system"); Lilienthal v. Kaufman, 239 Or. 1, 7, 395 P.2d 543, 545 (1964) (discussing the inadequacy of lex loci as applied to contract cases because the place of making the contract is often fortuitous). See also Katzenbach, Conflicts on an Unruly Horse: Reciprocal Claims and Tolerances in Interstate and International Law, 65 YALE L.J. 1087, 1091-93 (1956).

14. The Supreme Court of Wisconsin noted its dissatisfaction with these rules, stating that today the rights of parties may change minute by minute as they cross state boundaries by car, train, or airplane, if the rules of the locus are to be applied. Wilcox v. Wilcox, 26 Wis. 2d 617, 629-30, 133 N.W.2d 408, 414 (1965). Professor Korn has suggested that the primary reason for the failure of the lex loci rules was their failure to recognize the significance of the parties' domiciles. Korn, supra note 11, at 961-62. See infra note 88 .

15. A. Mehren \& D. Trautman, Law of Multistate Problems: Cases and Materials on Conflict of Laws 34-35, fn * (1965). R. Cramton, D. Currie \& H. Kay, CONFLict of LAWS: CASES-COMMENTS-Questions 6-7 (3d ed. 1981). 
voluntary consent to apply that law, given in order to do substantial justice. ${ }^{16}$

Traditional conflicts law in this country has reflected the tension between the relatively flexible doctrine of comity and the inore rigid concept of vested rights. ${ }^{17}$ The public policy exception to the comity doctrine developed as a bridge between the two. ${ }^{18}$ The exception is rooted in Story's writings on comity, in which he emphasized that the limits of a forum's apphication of foreign law were reached when the forum found it repugnant to its own pohicy or prejudicial to its interests. ${ }^{19}$ The exception emphasized the forum's right and obhigation to maintain its own interests by refusing to apply an otherwise appropriate foreign law that would injure its own citizens. ${ }^{20}$

Thus courts have refused to apply lex loci delicti-law of the place-when the courts found the foreign law unfair or anachronistic in light of the forum's own pohicies. ${ }^{21}$ The forum will not apply a foreign law that is repugnant to its own law. ${ }^{22}$ In Loucks $v$. Standard Oil Co., ${ }^{23}$ the New York Court of Appeals estabhished a commonly quoted definition of the scope of the public pohcy exception, concluding that a foreign law shonld not be applied when it violates "some fundamental principle of justice, some prevalent conception of good inorals, some deep-rooted tradition of the common weal."24

But the public policy exception lacks analytical focus. Despite almost universal citation of the Loucks defimition, courts have failed to distinguisl1 between legislative policies reflected in the enactment of particular statutes and fundamental societal policies. California's cases point out the differing applications of the doctrine. Some California cases have interpreted Loucks as enunciating a standard for the public

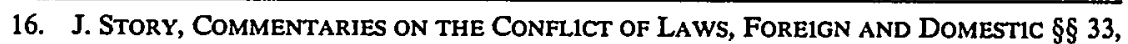
36, 38 (4th ed. 1852). The United States Supreme Court has emphasized in Story's definition a moral duty, deeper than mere courtesy, but never an absolute obligation. See Hilton v. Guyot, 159 U.S. 113, 165 (1895).

17. Compare, e.g., Katzenbach, supra note 13, at 1129 (discussing Beale's rigid concept of vested rights where territorial power was the supreme determinant of choice of law), with id. at 110204 (discussing Story's concept of comity as a jurisdiction's exercise of self-restraint while balancing competing policies). For a discussion of vested rights, see supra notes 7-12 and accompanying text.

18. See Wilcox v. Wilcox, 26 Wis. 2 d 617, 624, 133 N.W.2d 408, 411-12 (1965).

19. J. STORY, supra note $16, \S 38$.

20. Hilton v. Guyot, 159 U.S. 113, 164 (1895).

21. E.g., Kilberg v. Northeast Airlines, 9 N.Y.2d 34, 39-40, 172 N.E.2d 526, 528, 211 N.Y.S.2d 133, 135-36 (1961) (refusing to apply Massachusetts's $\$ 15,000$ maximum recovery in tort as unjust and arbitrary).

22. See In re Estate of Lathrop, 165 Cal. 243, 247-48, 131 P. 752, 754 (1913) (citing J. STORY, supra note 16, § 38); see also Wilcox v. Wilcox, 26 Wis. 2d 617, 623-24, 133 N.W.2d 408, 411 (1965) (reviewing Wisconsin's refusal to apply foreign laws that offend its own policies).

23. 224 N.Y. 99,120 N.E. 198 (1918).

24. Id. at 111,120 N.E. at 202. 
policy exception that requires more than a showing of a different outcome under California statutes. Thus a California court decided that an Oklahoma statute allowing guests to sue on ordinary negligence violates no fundamental policy of California regardless of a California law requiring gross negligence. ${ }^{25}$ Likewise, a Missouri law permitting a woinan who has remarried to receive alimony is no offense to inorality simply because California law would not allow the alimony payinents in these circumstances. $^{26}$

In contrast, there are California cases that have held that the mere existence of a different statute is sufficient to invoke the public policy exception. It has been held, for example, that since California law prohibits the bequest of more than one-third of an estate to charity, a contrary law will not be enforced as repugnant to California public policy. ${ }^{27}$ Since California does not allow parents to be sued for the torts of their children, a Hawaii law that conflicts by allowing such a law suit cannot be applied by way of comity. ${ }^{28}$ Moreover, since California has no law allowing hability for an automobile accident witliout fault, Mexico's strict liability law has been held to violate California public policy. ${ }^{29}$ And since California law refuses to exempt pension payments from writs of execution for family support, comity should not be invoked to apply such an Oregon exemption in violation of California policy. ${ }^{30}$ Here the court went so far as to say that with respect to exemption laws, comity should be granted only when the forum law is "practically the same" as the foreign law. ${ }^{31}$ When these latter four holdings are compared to the Loucks definition of the public policy exception, it becomes clear that application of the exception produces neither consistent nor predictable results.

The public policy exception was once ueeded, when rigid rules were applied, as an escape hatch to avoid absurd results. ${ }^{32}$ It arose not because of analytical accuracy, 1or because it provided for principled decisions, but as an alternative to the rigid and inappropriate requirements of vested rights. ${ }^{33}$ Currie has empliasized the extent to which the

25. Loranger v. Nadeau, $215 \mathrm{Cal} .362,366-67,10$ P.2d 63, 65 (1932).

26. Biewend v. Biewend, 17 Cal. 2d 108, 114, 109 P.2d 701, 705 (1941).

27. In re Estate of Lathrop, 165 Cal. 243, 247-48, 131 P. 752, 754 (1913).

28. Hudson v. Von Hamm, 85 Cal. App. 323, 329, 331, 259 P. 374, 377, 378 (1927).

29. Victor v. Sperry, 163 Cal. App. 2d 518, 524-26, 329 P.2d 728, 732-33 (1958).

30. In re Marriage of De Lotel, 73 Cal. App. 3d 21, 24, 140 Cal. Rptr. 553, 555 (1977).

31. Id.

32. B. Currie, Selected Essays on the Conflict of Laws 288 (1963). Professor Currie emphasized that the public policy exception served as a respectable means of avoiding application of the law designated by the vested rights rules as controlling law, where that law had no rational relation to state interests in the dispute. Id. at 133-34 \& n. 27.

33. Paulsen \& Sovern, Public Policy in the Conflict of Laws, 56 Colum. L. REv. 969, 980-81 (1956). 
vested rights rules nullified the interests of involved states, thus requiring a system comphicated with means of avoiding such results. One of these was the public policy exception. ${ }^{34}$ Both academics and courts have severely criticized the public policy exception and its parent, the comity doctrine. ${ }^{35}$ Critics have assailed the public policy exception as too easy to use without hard legal thinking. ${ }^{36}$ It has been used as a substitute for the intellectual exertion necessary to find appropriate factors. ${ }^{37}$ The public policy exception requires no discriminating distinctions; it allows local law to control even when the litigation has no connection to the forum. ${ }^{38}$

As a rationale apphied to choice-of-law questions, the public policy doctrine has been criticized as overbroad and rigid, an "intolerable affectation of superior virtue," 39 and as containing no principles. ${ }^{40}$ Both comity and the public policy doctrine have been assailed for their uncertainty ${ }^{41}$ and lack of analytical structure, ${ }^{42}$ for containing no objective standards, ${ }^{43}$ and for containing no predictability. ${ }^{44}$ The public policy exception has also been derisively labeled as a blunt tool ${ }^{45}$ and as a dangerous cure-all for the problems of vested rights rules. ${ }^{46}$

\section{Modern Policy-Oriented Approaches}

Reactimg to criticisms of both the traditional vested rights rules and

34. B. Currie, supra note 32, at 180-81. Professor Currie asserted that a state had no right to apply its own public policy unless it had a legitimate interest in applying that policy to the dispute. Id. at 237. He also identified the device of characterization as a convenient escape hatch. Id. at 13233.

35. See infra notes $39-46$ and accompanying text.

36. Paulsen \& Sovern, supra note 33 , at 1016.

37. Id. at $987-88$.

38. Id. at $971,1016$.

39. Korn, supra note 11 , at 939,962 .

40. Katzenbach, supra note 13 , at 1103. Professor Katzenbach criticizes comity as a very general notion that leaves no way to deduce what the principles of conflicts law should be in a given case.

41. See Laker Airways v. Sabena, Belgian World Airlines, 731 F.2d 909, 937 (D.C. Cir. 1984) (emphasizing that comity is an elusive concept, producing inherently uncertain results); Gutierrez v. Collins, 583 S.W.2d 312, 317 (Tex. 1979) (pointing out that the combination of vested rights with the public policy exception resulted in an "unworkable, irrational system").

42. Note, Transnational Public Policy as a Factor in Choice of Law Analysis, 5 N.Y.L. ScH. J. INT'L \& COMP. L. 367, 368 (1984).

43. Lilienthal v. Kaufman, 239 Or. 1, 13, 395 P.2d 543, 548 (1964) (the public policy exception lacks "any even remotely objective standards;" a choice-of-law approach defining the interests involved would provide more definite criteria than the public policy argument).

44. See supra text accompanying notes 25-31 for examples of variations in application of the public policy exception; see also Wilcox v. Wilcox, 26 Wis. $2 \mathrm{~d} 617,624,133 \mathrm{~N} . \mathrm{W} .2 \mathrm{~d} 408,412$ (1965) (use of the public policy exception and other escape hatches to avoid unjust laws renders the entirc choice-of-law process less predictable).

45. Hopkins v. Lockheed Aircraft Corp., 201 So. 2d 743, 747 (Fla. 1967), aff'd, 394 F.2d 656 (5th Cir. 1968).

46. A. Ehrenzweig, A Treatise on the Conflict of Laws 472 (1962). 
the comity and public pohicy doctrines, twentieth century scholars and jurists have developed new choice-of-law approaches. The old rules frequently resulted in arbitrary apphication of an inappropriate state's law. In response, states have sought a inore principled ineans for protecting their own interests, as forum states, by applying their own law. In the last forty years over half the states have abandoned the traditional rules in favor of new methods focusing on the relationship of the parties and the dispute to each state and to the policies served by each state's conflicting law. ${ }^{47}$

By far the inost common inodern approach adopted has been soine form of the inost-significant-relationship analysis expressed in the Restatement (Second) of Conflict of Laws. The Restatement embodies several approaches: (1) the inost-significant-relationship test; ${ }^{48}$ (2) general primciples of choice of law such as evaluation of the policies of the foruin and other interested states, administrability, predictability, protection of justified expectations, and system needs in the hight of specific factual contacts; ${ }^{49}$ and (3) specific contacts to be weighed according to the type of dispute. ${ }^{50}$

Fourteen states have adopted the Restatement approach since $1965 .{ }^{51}$ These states vary in their interpretations of "inost significant relationship." Texas, for example, first adopted the Restatement approach in a 1979 torts case. ${ }^{52}$ While the Texas Supreine Court stated that significance should be construed in terms of the policies of the disputed laws, in fact it determined significance in that case by listing the contacts Texas had with the dispute rather than by discussing policies. ${ }^{53}$ Sinnilarly, in a contracts dispute in 1981, a lower Texas appellate court found determinative the situs where the contract was negotiated and perforined. ${ }^{54}$ In a 1984 wrongful death suit, the Texas Supreine Court for the first tine gave priority to the policies of the laws, listing contacts only to deternine whether each state had an interest as a result of those factors. ${ }^{55}$

47. See generally Kay, supra note 6, at 524-25, 591-92 (discussing choice-of-law rules or approaches currently in effect in each state).

48. "The rights and liabilities of the parties ... are determined by the local law of the state which ... has the most significant relationship to the occurrence and the parties under the principles stated in § 6." RESTATEMENT (SECOND) OF CONFLICT of LAws § 145(1) (1971); see also id., $\S 188(1)$.

49. $I d . \S 6$.

50. Id. $\S \S 145(2)$ (contract contacts), 188(2) (torts contacts); see also Kay, supra note 6, at 55256 (discussing the evolution of the Restatement (Second) approach).

51. See Kay, supra note 6, at 556-57.

52. Gutierrez v. Collins, 583 S.W.2d 312 (Tex. 1979).

53. Id. at 319.

54. Baron v. Mullinax, Wells, Mauzy \& Baab, Inc., 623 S.W.2d 457, 461 (Tex. Ct. App. 1981).

55. Duncan v. Cessna Aircraft Co., 665 S.W.2d 4I4, 421-22 (Tex. 1984) (refusing to apply New Mexico's law allowing an injured party to sign a categorical release of tortfeasors, in favor of a 
The Restatement's inclusion of both policy statements and itemized contacts has been criticized as internally inconsistent, ${ }^{56}$ as well as resulting in varying interpretations of "Inost significant relationship" by states adopting this approach. ${ }^{57}$

Robert Leflar created a second popular modern choice-of-law approach with his hist of choice-influencing considerations. ${ }^{58}$ Professor Leflar identified the important factors as predictability of results (particularly important in consensual transactions), maintenance of interstate and international order (that is, deference to the substantial interests of another state), judicial simplicity, advancement of the forum's governinental interests, and application of the better rule of law. ${ }^{59}$

This last factor is both the most distinguishing eleinent in Professor Leflar's approach and the most controversial. ${ }^{60}$ Three states explicitly follow Professor Leflar's entire approach including this better-law element. ${ }^{61}$ Wisconsin courts, applying the "better" law approach for twenty years, ${ }^{62}$ have identified the "better" law based on a variety of criteria: the law that reflects the current socio-economic facts of life (as opposed to an "anachronistic" law), ${ }^{63}$ the law that protects the injured rather than the insurance coinpanies, ${ }^{64}$ the law that is relatively new and that is consistent with the pohicies of workers' compensation, ${ }^{65}$ the law that enforces the legitimate expectations of the parties, ${ }^{66}$ and the law that is in force in a majority of states. ${ }^{67}$ The "better-law" approach has been questioned because its lack of objective standards opens the door to a greater use of judicial value judgments. ${ }^{68}$

Governmental interest analysis, originally developed by Brainerd

Texas law validating only the release of identified defendants: New Mexico policy would protect defendants, but here New Mexico had no interest because defendant was a Kansas corporation; Texas policy, on the other hand, would protect injured plaintiffs, and plaintiff here was a Texas resident).

56. See Professor Kay's discussion of the confusion that the "hybrid product" has caused. Kay, supra note 6 , at 552-56.

57. See id. at 558-62.

58. Leflar, Choice-Influencing Considerations in Conficts Law, 41 N.Y.U. L. REV. 267 (1966); see Heath v. Zellmer, 35 Wis. 2d 578, 595-96, 151 N.W.2d 664, 672 (1967) (discussing Professor Lefiar's factors).

59. Leflar, supra note 58 , at 282.

60. See Kay, supra note 6 , at $564,585-86$.

61. The states are Minnesota, New Hampshire, and Wisconsin. Id. at 564-66.

62. See Heath, 35 Wis. 2d. at 595-96, 151 N.W.2d at 672 .

63. Id. at 602,151 N.W.2d at 675 .

64. Haines v. Mid-Century Ins. Co., 47 Wis. 2d 442, 451, 177 N.W.2d 328, 333.(1970).

65. Hunker v. Royal Indem. Co., 57 Wis. 2d 588, 608-10, 204 N.W.2d 897, 907-08 (1973).

66. Schlosser v. Allis-Chalmers Corp., 86 Wis. 2d 226, 241, 271 N.W.2d 879, 886 (1978).

67. Lichter v. Fritsch, 77 Wis. 2d 178, 186, 252 N.W.2d 360, 364 (1977).

68. See Kay, supra note 6 , at $572,585-86$. 
Currie, ${ }^{69}$ is a third influential modern approach. California, the leading state to employ this approach, ${ }^{70}$ applies it in a series of steps. First, forum law is applied unless the law of another state is claimed. If such a claim is made, the court then deternines whether, given the policy purposes of the conflicting laws and the state's contacts with the dispute, each state has an interest in applymg its law. Fimally, if there is a true conflict, ${ }^{71}$ the court applies the doctrine of comparative impairment, determining whicl state's interest would be most greatly impaired if its law were not applied. ${ }^{72}$ The interests of each state in applymg its law depend on whether the state has such contacts with the dispute tliat the purposes of its law-inost commonly compensation of plamtiffs, ${ }^{73}$ protection of defendants from excessive liability, ${ }^{74}$ deterrence of wrongful conduct, ${ }^{75}$ and occasionally protection of the public ${ }^{76}$-would be furthered by applying that law. California's use of the comparative impairment approacli has been criticized as providimg no guidelines and encouragimg courts to make value judgments, without producing any greater uniformity than conld be achieved by following Currie's original proposal, that $\mathrm{m}$ all cases of true conflict foruin law sliould be applied. ${ }^{77}$

In 1954, New York moved away from the old vested riglits concept and adopted a fourth modern approach: the "center of gravity."78 Early cases tended to find the center of gravity by counting and grouping contacts. In an automobile accident case, for example, the court einpliasized the parties' domicile, the accident vehicle's state of registration, and the start and end of the trip during which the accident occurred. ${ }^{79}$ More recently New York courts have focused on the interests of each state.

69. See generally B. CURRIE, supra note 32 (collection of his early expositions of governmental interest analysis).

70. See Kay, supra note 6 , at $542-44$.

71. A true conflict is a situation in which the applicable laws of two or more states connected to the dispute differ, and each state has an interest in applying its policy. Id. at 178 .

72. Bernhard v. Harrah's Club, 16 Cal. 3d 313, 320, 546 P.2d 719, 723, 128 Cal. Rptr. 215, 219, cert. denied, 429 U.S. 859 (1976). The comparative impairment element is a subsequent addition to Professor Currie's governmental interest analysis approach. Kay, The Use of Comparative Impairment to Resolve True Conflicts: An Evaluation of the California Experience, 68 CALIF. L. REV. 577 (1980).

73. Reich v. Purcell, 67 Cal. 2d 551, 556, 432 P.2d 727, 731, 63 Cal. Rptr. 31, 35 (1967).

74. Offshore Rental Co. v. Continental Oil Co., 22 Cal. 3d 157, 163-64, 583 P.2d 721, 725, 148 Cal. Rptr. 867, 871 (1978).

75. Hurtado v. Superior Court, 11 Cal. 3d 574, 583, 522 P.2d 666, 672, 114 Cal. Rptr. 106, 112 (1974); Kasel v. Remington Arms Co., 24 Cal. App. 3d 711, 733-34, 101 Cal. Rptr, 314, 329-30 (1972).

76. Bernhard, 16 Cal. 2d at 322-23, 546 P.2d at 725, 128 Cal. Rptr. at 221.

77. Kay, supra note 72, at 579, 609-11; Note, Conflict of Laws, 65 CALIF. L. REv. 290, 303 (1977).

78. Auten v. Auten, 308 N.Y. 155, 160-61, 124 N.E.2d 99, 101-02 (1954).

79. Babcock v. Jackson, 12 N.Y.2d 473, 482, 191 N.E.2d 279, 284, 240 N.Y.S.2d 743, 750 (1963). 
For example, in a wrongful death action involving the death of a New York resident at his brother's home in Maine, New York had a substantial interest in protecting the decedent's family. Maine had no corresponding interest, however. Its limitation on recovery focused only on the remedy and not on regulation of the defendant's conduct. The defendant had not rehed on that limitation. ${ }^{80}$ Thus Maine had no interest in protecting the defendant's reliance, nor in protecting the defendant as a Maine resident, since the defendant was no longer a Maine resident at the time of the law suit. Since New York's interests were stronger, New York was the center of gravity for the suit and its law was applied. ${ }^{81}$

The center-of-gravity approach has been criticized for failing to identify how significant contacts slould be distingnished from insignificant contacts and for "obscuring the connection between the facts of the cases and the policies of the conflicting laws."82

To meet these concerns, New York courts began to use the language of interest analysis in their center-of-gravity test. In Miller v. Miller, the Court of Appeals emphasized that the significant factors in conflicts analysis were state interests reflected $\mathrm{m}$ the purposes of its law. ${ }^{83}$ A year later the court talked only in terns of the state's interest. ${ }^{84}$ In 1985 the Court of Appeals, after referring to these cases, concluded that New York's approach to conflict of laws was governmental interest analysis. ${ }^{85} \mathrm{New}$ York's governmental interest analysis focuses on the significance of contacts as measured by the interests of each state reflected in the policies of its laws; ${ }^{86}$ it does not, however, contain the distinct steps used by California courts.

Eacl of these modern techniques-the most-significant-relationship test, the choice-influencing considerations, governmental interest analysis, and the center-of-gravity approach-attempts to avoid arbitrary and fortuitous results. Each emphasizes the state's interest rather than geographic location. Each creates a principled approach by narrowly defining the underlying state policy for each disputed law and recognizes that the extent to which applying the state's law can further its policy depends on the relevant contacts the state has with the dispute.

Yet academics have criticized these modern choice-of-law

80. Although the defendant might have relied on Maine's limitation in purchasing insurance, the court observed that it had not claimed such a reliance. Miller v. Miller, 22 N.Y.2d 12, 18-22, 237 N.E.2d 877, 880-82, 290 N.Y.S.2d 734, 739-42 (1968).

81. Id. at 22,237 N.E.2d at 883,290 N.Y.S.2d at 742.

82. Kay, supra note 6 , at 537-38.

83. 22 N.Y.2d at $15-16,237$ N.E.2d at 879,290 N.Y.S.2d at 737.

84. Tooker v. Lopez, 24 N.Y.2d 569, 576, 249 N.E.2d 394, 398, 301 N.Y.S.2d 519, 525 (1969).

85. Schultz v. Boy Scouts of America, Inc., 65 N.Y.2d 189, 197, 480 N.E.2d 679, 684, 491 N.Y.S.2d 90, 95 (1985).

86. Id. 
approaches. ${ }^{87}$ Courts differ widely over what policies-and therefore what state interests-are reflected in particular laws. Moreover, no objective standards are provided for weighing the effects of two laws in determining the "most significant relationship," the "better" law, comparative impairment, or the "center" of gravity. The failure of these approaches to produce consistent results ineans that parties inay well receive different decisions depending on the forum selected. This in turn results in increased forum-shopping and hitigation of choice-of-law issues.

Modern choice-of-law approaches provide a classic example of the ever-present tension between the desire for equitable results and the need for predictability. Though admittedly inequitable, the vested rights rules were predictable. In contrast, the inodern approaches reflect an effort to have more equitable results at the expense of predictability. As no workable proposal for a inore predictable set of rules has yet emerged, ${ }^{88}$ policy-oriented choice-of-law approaches seein firmly entrenched at this time. Even their strongest critics would not suggest returning to the old vested-rights rules. ${ }^{89}$

\section{II}

\section{Comity and Public Policy in the Modern Age}

States continumg to employ traditional rules inaintain the comity and public policy doctrines to avoid inappropriate results. In states employing one of the modern approaches, however, it remains unclear

87. E. SCOLES \& P. HAY, supra note $7, \S 2.16$ (discussing the almost insoluble dilemma facing courts attempting to determine the policies and relative interests of relevant states, resulting in unpredictable, ad hoc results). See generally Reese, Choice of Law: Rules or Approach, 57 CoRNELL L. REV. 315 (1972) (emphasizing the difficulty of assessing the relative strengths of two states' policies, and proposing new choice-of-law rules for types of disputes requiring uniformity of results); Rosenberg, The Comeback of Choice-of-Law Rules, 81 CoLUM. L. REv. 946 (1981) (governmental interest analysis ignores legislative policies favoring simplicity, predictability, and multi-state harmony, while it necessitates subjective, and therefore dangerous, value judgments).

Professor Korn states that in reacting to the rigidity of lex loci, the conrts have gone too far, substituting extreme flexibility with no rules at all. Korn, supra note 11, at 962-63. Professor Korn further insists that the interests of the individual parties in justice in a particular case should be more important than the interests of the state as emphasized in interest analysis or in the Restatement approach. Id. at 968.

88. Proposals have been made for more rule-oriented approaches. Professor Korn proposes that the common domicile of the parties should be the preeminent choice-of-law rule, based on the concept of a social contract and consent of the governed, as well as communally shared goals, conditions, and concepts of morals. The individual's choice of a state, Professor Korn says, signifles his acceptance of its authority to regulate his affairs. Locus law should normally be appropriate in a split domicile situation, but to ensure justice the court should also look to such factors as the state both parties have strong associations with, or the benefits to each party from the transaction that produced the law suit. Korn, supra note 11, at 799, 966-67; see also Neumeier v. Kuehner, 31 N.Y.2d 121, 127-28, 286 N.E.2d 454, 457-58, 335 N.Y.S.2d 64, $69-70$ (1972) (suggesting rules for deciding guest-host accident cases). These proposals can be applied only to certain types of cases and do not resolve the problems inherent in inore complex cases.

89. See Rosenberg, supra note 87 , at $958-59$. 
whether comity and public policy arguments continue to perform a significant function.

This Comment argues that in such jurisdictions, comity and the public policy exception no longer serve as a necessary corrective measure to unduly rigid choice-of-law rules. Moreover, comity is little more than the courtesy in consideration of which a state honors a foreign law. A court invokes comity only after it has decided to apply foreigu law to the dispute before it. ${ }^{90}$ The public policy exception is purely duplicative, and therefore obsolete, because the "public policies" employed defensively in earlier times are already an imtegral part of modern analysis, because that analysis determines the policies underlying the laws in dispute and the relevant contacts giving rise to the competing interests. The analytical framework provided by modern approaches forces courts to focus the pohicy issues and thus to state principled reasons for their decisions. The broad public policy exception has no such structure and only dilutes this focus.

\section{A. Older Public Policy Cases Under Modern Analysis}

The irrelevance of the public policy exception under a modern approach can be illustrated by reanalyzing a few early California cases decided under the doctrime. ${ }^{91}$ In Hudson v. Von Hamm, ${ }^{92}$ a governess was injured by the actions of a child in Hawaii. Hawaii law permitted parents to be sued for the torts of their children while Cahifornia law did not. The governess sued the Hawaii parents in California. The court noted that the plaintiff's residence had not been alleged and therefore assumed that the plamtiff was a resident of Hawaii. It cited the traditional rule that generally, a foreign citizen may bring a suit if a forum citizen could do $50 .{ }^{93}$ Where California had a positive statute conflicting with the Hawain law, however, that statute could be taken to stand for forum pubhic policy, forcing the comity doctrine to yield. ${ }^{94}$ The court therefore declined jurisdiction.

A California court deciding this case under governmental interest analysis today would probably note that the policy behind the Hawaii

90. 12 CaL. JuR. Conflict of Laws $\$ \S 6,19$ (1974). See, e.g., Loranger v. Nadeau, 215 Cal. 362, 366 (1932) (plaintiff's right to sue accrued in Oklahoma because the accident occurred there; under comity California will treat that right as valid because it violates no fundamental California public policy); Hudson v. Von Hamm, 85 Cal. App. 323, 326-29, 259 P. 374, 376-77 (1927) (deciding first that plaintiff's cause of action arises only under foreign law, then discussing whether to allow that cause of action by comity).

91. The modern analysis used will be California's governmental interest analysis, because the cases discussed are California cases. Application of any other modern approach would, however, yield the same outcomes as those presented here.

92. 85 Cal. App. 323, 259 P. 374 (1927).

93. Id. at $327,259 \mathrm{P}$. at $376-77$.

94. Id. at $330-31,259$ P. at 378 . 
statute was to ensure adequate compensation to an injured plaintiff, ${ }^{95}$ whereas the primary purpose of the California statute was to limit parents' liability to those accidents in which they had participated in the wrong. ${ }^{96}$ Since the plaimtiff was a Hawaii citizen, and since the parents to be protected by California law were not California citizens, Hawaii would be the only state with an interest in this dispute. Moreover, a second policy behind the Hawain law could have been to regulate the parents' conduct-that is, to cause parents to exercise greater control over their children's actions. Since the tortious conduct occurred in Hawain, Hawaii would have a further interest in the dispute.

Thus under modern analysis, a California court imght well apply Hawain law and allow the suit, recognizing that only Hawaii had an interest in the outcome and that the case therefore presented a false conflict. Instead, the court used the public policy exception without defining California public policy beyond saying that the statute was the pohcy. ${ }^{97}$ The modern approach would incorporate a policy analysis, but refine it by weighing it against California's contacts (or lack thereof) with the dispute. Not only is there no value in reiterating this policy analysis in a separate public pohicy exceptioll argument, but the modern analysis narrows, focuses, and structures the significance of the policy in ways that the older public policy exception does not. Hawan̈ policy would be tied to the fact that both parties were Hawain residents; California would have no interest in protecting parents innocent of fault because the parents were $110 t$ California citizens.

I11 Estate of Lathrop, ${ }^{98}$ an heir at law challenged a will made in New York that bequeathed virtually an entire estate, including personal property located in California, to charity. The California Supreme Court stated that under traditional rules the distribution of the decedent's personal property would ordinarily be governed by the law of the doimicile. ${ }^{99}$ In this case, however, the court found that Cahfornia had declared a public policy by adopting a statute disallowing bequests to charity of inore than one-third of an estate. The court therefore apphied California law. ${ }^{100}$

A court could reach the same result based on modern governmental interest analysis. The court would probably have found that New York's purpose in allowing an unlimited bequest to charity was to respect a decedent's right to dispose of his property as he chose and to support

95. Rathburn v. Kaio, 23 Haw. 541, 544 (1916) (the statute's intent was to create greater likelihood of adequate compensation than if action could be taken only against the child).

96. Hudson, $85 \mathrm{Cal}$. App. at 326, 259 P. at 376.

97. Id. at $328-29,331,259$ P. at 377,378 .

98. 165 Cal. 243, 131 P. 752 (1913).

99. Id. at $247,131 \mathrm{P}$. at 754 .

100. Id. at $247-48,131$ P. at 754 . 
charitable institutions. ${ }^{101}$ Since the decedent had been doiniciled in New York, New York would have an interest in applying its policy.

The policy of the California statute would be to protect the decedent's family from total deprivation under the will and possible poverty and dependence on the state. The case failed to indicate whether the heir was a California citizen, but under modern analysis the heir's domicile would be a crucial factor. If he were not a Cahifornia resident, California would have no interest in applying its policy and New York law would control. If the heir were a California citizen, however, the court would recognize a true conflict and would thus apply comparative impairnent. Under this test, it could find that apphication of New York law would completely impair California's interest because the California heir would mherit nothing under the will-exactly the condition California law intended to prevent. If, on the other hand, California law were applied, New York's interest would be only partially impaired, as the decedent could still bequeath up to one-third of his estate to charity. Additionally, the California interest would reach only those wills executed by decedents who left personal property in California. ${ }^{102}$ Thus in this case, as in Hudson v. Von Hamm, ${ }^{103}$ a court using interest analysis would analyze California policy in a more focused manner than it could by using the public policy exception. Rather than simply state that the statute is the policy, a modern court would define the purposes of the statute and relate them to California's actual contacts in the dispute.

\section{B. Modern Restrictions on Comity and Public Policy Doctrines}

Thougl courts applying modern choice-of-law approaches liave referred to the public policy exception, they liave often limited its application. In Ehrlich-Bober \& Co. v. University of Houston, ${ }^{104}$ for example, a New York plaintiff securities dealer sued the University of Houston in New York for breacl of contract. The New York Court of Appeals considered a choice-of-law issue surrounding the assertion of jurisdiction. Texas law allowed suits against the Umiversity only in two Texas counties. In deciding whether to apply Texas law, the court pointed out that the use of comity by the fornm was entirely voluntary. ${ }^{105}$ The court then

101. See id. at $247,131 \mathrm{P}$. at 754.

102. Similar logic is employed in Bernhard v. Harrah's Club, 16 Cal. 3d 313, 546 P.2d 719, 128 Cal. Rptr. 215, cert denied, 429 U.S. 859 (1976). There, California law was applied to hold a Nevada casino liable for serving alcohol to obviously intoxicated California residents who were subsequently involved in an accident in California. The court stated that Nevada's interest in protecting its tavern owners would be less impaired than California's because the reach of California law would extend only to those taverns that advertised heavily in California. Id. at 323,546 P.2d at 725, 128 Cal. Rptr. at 221.

103. See supra text accompanying notes $92-97$.

104. 49 N.Y.2d 574, 404 N.E.2d 726, 427 N.Y.S.2d 604 (1980).

105. Id. at 580,404 N.E.2d at 730,427 N.Y.S.2d at 608. 
evaluated the interests of the two states. It noted that Texas had restricted jurisdiction primarily for adininistrative convenience rather than as a policy that went to the "heart of a governmental function." 106 New York, on the other hand, had a strong interest in its status as a center for commercial transactions, particularly when the controversy was centered in New York as in this case. The court concluded that comity could not preclude New York from asserting its law. ${ }^{107}$

Thus the New York court, although using the language of comity, brought inodern choice-of-law analysis in by the back door. It refused to apply arbitrarily the Texas venue statute in a situation in which the forum had a strong interest. In effect, the court stated that New York law was selected because of New York's strong commercial contacts with the dispute, and that this outweighed any arguments for comity. The court confused the issue, however, by identifying comity as the central issue and interest analysis as an exception to that doctrine.

Another court applied similar logic in treating the public policy doctrine as subservient to an analysis of the forum's actual interest. In Jarvis v. Ashland Oil, Inc., ${ }^{108}$ a general contractor's employee had been injured while working on a client's premises. The employee sued the client, who then mipleaded the general contractor on a contract clause requiring the contractor to indemnify the client for any injuries resulting from the client's neghigence at the site. By statute Ohio did not permit such exculpatory clauses. ${ }^{109}$ There were, however, several factors mitigating against the application of the Ohio statute. The company was a Kentucky corporation and the parties had explicitly chosen Kentucky law to govern any dispute. ${ }^{110}$ The Ohio plaintiff was not a party to the contract and had no direct interest in the indemnification issue. ${ }^{111}$ Finally, Ohio had an underlying public policy entitling parties to voluntary agreements to enforcennent under the agreed terms. ${ }^{112}$ Although the Ohio Suprene Court found that the exculpatory clause violated Ohio statutory policy, it ultimately refused to enforce its own state's public policy. It held instead that because Ohio had insufficient interest in the dispute, it could have no interest in applying its public policy. ${ }^{113}$ The court thus recognized that the fornm's interest in the dispute was the critical factor in resolving the choice-of-law question. As a result it was forced to limit the public policy exception to avoid inappropriately applying forum law.

106. Id. at 582, 404 N.E.2d at 731, 427 N.Y.S.2d at 609.

107. Id.

108. 17 Ohio St. 3d 189, 478 N.E.2d 786 (1985).

109. Id. at 192,478 N.E.2d at 789.

110. Id. at $189-90,478$ N.E.2d at 788.

111. Id. at $191-92,478$ N.E.2d at $788-89$.

112. Id. at 192,478 N.E.2d at 789.

113. Id. (the forum must have a "materially greater interest"). 


\section{Recurrence of Public Policy Arguments}

Although California has rehed on the governmental interest analysis approach for twenty years, the public policy and comity doctrines occasionally reappear for no apparent reason. In Severn v. Adidas Sportschuhfabriken, ${ }^{114}$ for example, an appellate court considered the validity of process served in a California civil suit while defendants were appearing in Florida as plaintiffs in another law suit. The defendants claimed the common law immumity rule precluding service of civil process while they were attending another court. ${ }^{15}$ The court traced the reasons behimd the immunity doctrine, noting that it existed solely for the benefit of the court, to promote judicial administration, ${ }^{116}$ and to avoid discouraging persons from appearing voluntarily in litigation where their presence was desirable. ${ }^{117}$

It then declared the validity of California process served in Florida to be a matter of California public policy. ${ }^{118}$ Since plaintiffs could have served process on defendants at their residence in Europe under modern service-of-process rules, quashing process would not enhance the purposes of immunty. ${ }^{119}$ Because California public policy required voiding the immunity rule whenever its purposes were not enhanced by enforcement, ${ }^{120}$ the California court held that even if immunity were the rule in Florida, the immumity rule should not be honored by way of comity. ${ }^{121}$

The court did not indicate why governmental interest analysis was not applied. Under that approach, the court would have first deterinined whether Florida would apply the immunity rule in these circumstances, in order to determine whether a choice-of-law issue existed. ${ }^{122}$

The court would probably have found that Florida maintained the rule of immunity from civil process. ${ }^{123}$ The California court would then determine that the pohicy underlying Florida's rule is to encourage the voluntary appearance of persons in its law suits. In this case, the parties served-although defendants in the California suit-were nonresident plaintiffs in the Florida suit. Nevertheless, the immunity rule generally

114. 33 Cal. App. 3d 754, 109 Cal. Rptr. 328 (1973).

115. Id. at 756, 109 Cal. Rptr. at 329; see 72 C.J.S. Process $\S 80(a)(1)$ (1951).

116. Severn, 33 Cal. App. 3d at 757, 109 Cal. Rptr. at 329.

117. Id.

118. Id. at 763, 109 Cal. Rptr. at 333.

119. Id. at 763, 109 Cal. Rptr. at 334. As the court noted, forum non conveniens rather than immunity would be the proper way to avoid the lawsuit if not appropriate in California. $I d$. at 758 , 109 Cal. Rptr. at 330.

120. Id. at 762, $109 \mathrm{Cal}$. Rptr. at 333.

121. Id. at 763-64, 109 Cal. Rptr. at 333-34.

122. See Hurtado v. Superior Court, 11 Cal. 3d 574, 580, 522 P.2d 666, 669, 114 Cal. Rptr. 106, 109 (1974).

123. See Stokes v. Bell, 441 So. 2d 146 (Fla. 1983). 
applies to plaintiffs as well as defendants. ${ }^{124}$ Since the defendants could have been served at their domicile in Europe, however, Florida's imınunity rule would not create greater incentives for their Florida court appearance. Thus Florida had no interest in enforcing its rule. California, on the other hand, had an interest in maintaining jurisdiction over defendants in the California law suit and in upholding the rights of California creditors (plaintiffs in the suit) to pursue legal action in its courts. ${ }^{125}$ Severn, then, presented a false conflict. Under governmental interest analysis, only California had an interest, and thus California law should control.

In Severn, the court could have reached the saine result under either governmental interest analysis or the public pohicy exception. In applying interest analysis the court would have made clear its reasons by analyzing each state's interests and outlining its own decisionmaking process. In contrast, the court's public policy arguinent did not explain why California's pohicy was preferable to Florida's.

In In Re Marriage of De Lotel, ${ }^{126}$ the Navy had honored a California ex-wife's writ of execution on her husband's military pension for unpaid support. ${ }^{127}$ The Oregon ex-husband sued to prevent enforcement. Oregon law would have exempted such payments from execution, ${ }^{128}$ while the California exemption statute did not apply in cases of courtordered support and provided exemptions only for California residents. ${ }^{129}$ The court refused to apply the Oregon law as a matter of comity. It stated that exemption laws apply only to the remedy-thus a procedural issue traditionally governed by foruin law-and that in any case public policy would allow applying Oregon law only when the forum law was "practically the same."130

The court could have reached the saine result under governmental interest analysis, and in doing so would have defined each state's interests inore precisely. Oregon's exemption law presumably reflects Oregon's interest in protecting its debtors' basic sources of support from legal action. ${ }^{131}$ The California family support exception expressed California's

124. Stewart v. Ramsay, 242 U.S. 128, 130-31 (1916).

125. Severn, 33 Cal. App. 3d at 760, 109 Cal. Rptr. at 331.

126. 73 Cal. App. 3d 21, 140 Cal. Rptr. 553 (1977).

127. Id. at 23, $140 \mathrm{Cal}$. Rptr. at 554 .

128. OR. REv. STAT. $\$ 23.170$ (amended in 1979, after this case, to except executions for a support obligation from the general exemption).

129. CAL. Civ. Proc. CODE $\$ 690.18$ (West 1980) (repealed in 1982 and replaced by $\$ 703.070$ (West Supp. 1986) (no exception for child or spousal support except as ordered by the court using its discretion)).

130. De Lotel, 73 Cal. App. 3d at 24, 140 Cal. Rptr. at 555.

131. Oregon cases have not discussed the policies underlying the Oregon exemption law. But cf. Roosevelt v. Roosevelt, 117 Cal. App. 3d 397, 402, 172 Cal. Rptr. 641, 644 (1981) (discussing the purposes of California's exemption statute). 
interest not to relieve the husband of his obligation to pay support. ${ }^{132}$

Here exists a true conflict. Both states have an interest: Oregon in protecting the ex-husband, California in protecting the ex-wife. Enforcement of either law would impair the interests of the other state. The court might well find, however, that enforcing the Oregon law would create greater impairment in that it would not only frustrate California's interest im protectimg the ex-wife, but would also fail to deter the exhusband's wrongful conduct im failing to pay his legally required support payments. Applying Califorma law would impair Oregon's interest only in situations in which an Oregon ex-husband failed to fulfll his obligations to a California ex-wife. Thus the court might well reach the same conclusion under governmental interest analysis that it did under the public policy argument. Underlymg that analysis is the fact that the two laws are not "practically the same." 133 By applying governmental interest analysis, the court would have more precisely defined the actual interests affected by its decision instead of dredging up an outdated procedural/substantive dichotomy as the basis for its analysis.

\section{Summary: Handling Public Policy Questions Under Modern Approaches}

As the cases above illustrate, moderu approaches to choice of law do not suggest that public policy is no longer a relevant factor. Rather, they incorporate public policy as the central focus in every choice-of-law decision-not only as an occasional exception.

Each inodern approach employs a distinct methodology. Under governmental interest analysis, a true conflict exists only when the underlying pohcies of conflicting laws establish that each state does mdeed have an imterest im applying its law given the facts of the particular case. ${ }^{134}$

Professor Leflar's choice-influencing considerations reflect considerations of comity by mcluding the maintenance of interstate and interuational harmony. Professor Leflar also emphasizes the forum's primary conceru with advancing its own governmental interests. ${ }^{135}$ As in governmental interest analysis, the forum's interest cannot be defined until the pohicies of the law are identified. In addition, determining the better law involves weighing and evaluating the significance of public policy considerations. ${ }^{136}$

To the extent that the Second Restatement's most-significant-rela-

132. In re Smallbone, 16 Cal. 2d 532, 534, 106 P.2d 873, 874 (1940).

133. See supra text accompanying note 31 .

134. See supra text accompanying notes 69-77.

135. Leflar, supra note 58 , at 290.

136. See supra text accompanying notes 58-68; see also Leflar, supra note 58, at 298 (better law 
tionship test considers the policies of the disputed laws to determine the significance of a state's relationship to the dispute, each state's public policy is inherently part of the test. ${ }^{137}$ Similarly, the center-of-gravity test considers the purposes of the disputed law, ${ }^{138}$ thus incorporating the relevant state public policy concerns. ${ }^{139}$

\section{III}

\section{Public Policy IN 1985: A Revival?}

In 1985, three state high court decisions recognized a public policy exception argninent. ${ }^{140}$ Since these cases were all decided in inodern choice-of-law jurisdictions, the comity and public policy exception arguments should have been rendered obsolete. These cases inay reflect a belief that the modern analyses have failed to consider all relevant issues, or they inay signal a retreat froin the inodern approaches, or they may be simply the result of confusion on the part of the courts. None of the courts explained its return to an obsolete doctrine. Indeed, as previously argued, ${ }^{141}$ there is no adequate justification. By including comity and public pohicy arguinents the courts in these cases have confused their choice-of-law analyses. Thus, any trend that might be inferred froin these cases should be cut short.

\section{A. Boardnıan v. United Services Autonıbile Association}

The first of these decisions is Boardman v. United Services Automobile Association. ${ }^{142}$ Boardman involved a Nebraska insured who held an insurance policy issued in Nebraska on his three Nebraska autoniobiles. The policy excluded uninsured notorist coverage for accidents in any noninsured car owned by a relative of the insured. ${ }^{143}$ Nevertheless, the insured sued to force his insurance company to cover his son's accident in Mississippi with an uninsured notorist, while his son was driving a car, not insured under the policy, that the son had bought in Mississippi for his suinmer job there.

The Mississippi Suprente Court unquestioningly accepted the lower

is often the one that upholds fair transactions entered into in good faith, except for those deemed "grossly immoral or antisocial" or offending the court's "strongly held views").

137. See supra text accompanying notes 48-57.

138. Miller v. Miller, 22 N.Y.2d 12, 15-16, 237 N.E.2d 877, 879, 290 N.Y.S.2d 734, 737 (1968).

139. See supra text accompanying notes 78-82.

140. Boardman v. United Services Automobile Ass'n, 470 So. 2d 1024 (Miss.), cert. denied, 106 S. Ct. 384 (1985); Schultz v. Boy Scouts of America, Inc., 65 N.Y.2d 189, 480 N.E.2d 679, 491 N.Y.S.2d 90 (1985); Wong v. Tenneco, Inc., 39 Cal. 3d 126, 702 P.2d 570, 216 Cal. Rptr. 412 (1985).

141. See supra text accompanying notes $90-103$.

142. 470 So. 2d 1024 (Miss.), cert. denied, 106 S. Ct. 384 (1985). This case was filed in federal court in Mississippi and subsequently certified by the Fifth Circuit to the Mississippi Supreme Court for determination of the choice-of-law questions at issue. Id. at 1027.

143. Id. at 1029. 
court's determination that this exclusion clause would be valid under Nebraska law but invalid under Mississippi law. ${ }^{144}$ The relevant Mississippi statute states that no automobile hability policy shall be issued unless the insurer undertakes to pay the injured person for sums he is entitled to from uninsured motorists. ${ }^{145}$ Mississippi courts had held the statute to be violated by any restrictive language in the policy. ${ }^{146}$ The court then turned to the choice-of-law issue. Mississippi, it said, follows the Restatement's approach to choice of laws, which it labeled the "center of gravity" approach, as qualified by the public policy exception. ${ }^{147}$

The court apphed this test by defining each state's contacts. Nebraska was the place where the contract was negotiated and where most of it was performed, and it was the primcipal place of risk as understood by the parties. The court determined that the son should be considered to have been hiving with his parents in Nebraska at all relevant times. ${ }^{148}$ The son attended school im Mississippi and bought the car in Mississippi for his summer job. Simce the question was which parties were insured rather than the scope of the risk, the court found that the Mississippi contacts were not significant to the issue. ${ }^{149}$

Having determined that the Nebraska contacts were inore significant, the court turned to its public policy exception. The court stated that enforcing the public pohicy exception depended on how "fundamental" and "inviolable" the particular policy was. ${ }^{150}$ Without defining what public policy was at issue other than the policy reflected in Mississippi's Uninsured Motorist Statute, the court decided that Mississippi had no interest in upholding its public policy im this situation where the Nebraska contacts were so strong. ${ }^{151}$

The significant question here is why the Mississippi court raised the public policy issue at all. The court rightly determined that the signiflcance of a contact depends on whether it relates to the question at issue in the conflicting laws. Had the court gone one step further, to define the policies of the two states' conflicting laws rather than simply their contents, ${ }^{152}$ the case could have been resolved without reference to a separate public policy argument. The court would have defined the policies

144. Id.

145. Miss. Code ANN. \$ 83-11-101 (1972); see also Lowery v. State Farm Mutual Auto. Ins. Co., 285 So. $2 \mathrm{~d} 767,770$ (Miss. 1973) (discussing the policy underlying the statute; that is, to protect the injured person).

146. Lowery, 285 So. $2 \mathrm{~d}$ at 770.

147. Boardman, 470 So. $2 \mathrm{~d}$ at 1031.

148. Id. at 1035-36.

149. Id. at 1034-36.

150. Id. at 1038.

151. Id. at 1039.

152. See supra notes $48-57$ and accompanying text. 
and weighed the contacts as follows: Nebraska's policy in allowing such exclusionary clauses is to uphold the validity of a contract according to the reasonable expectations of the parties. Nebraska also is concerned to allow insurance coinpanies that do business in Nebraska to adjust policy exclusions and premiums on an mdividualized basis and to restrict coverage to those family vehicles for which an insured has paid premiums. The Nebraska contacts are significant to such policies; the imsurance company entered into a contract with an insured who hived in Nebraska and did most of his driving in Nebraska.

The purpose of the Mississippi Uninsured Motorist Statute is to ensure that a driver is protected even when injured by an uninsured motorist. ${ }^{153}$ For this reason, the statute guarantees a driver who carries an automobile liability policy that he will be indemnified in any accident unless he is responsible for the accident. In this case the Mississippi contacts-the son's purchase of the car, his schooling, his summer job, and the place of injury-do not involve this policy designed to protect Mississippi residents who insure. Neither the insured nor the imjured plaintiff is a Mississippi resident. The contract was not inade in Mississippi nor did the parties intend that its focus would be in Mississippi. Thus, in this case, Nebraska law should be applied because the Nebraska contacts are inore ineaningful, in terms of its policy, than Mississippi's. By this analysis each state's policy is identified and related to its contacts. Public policy does not operate as an exception, but inheres in the basic analysis.

\section{B. Schultz v. Boy Scouts of America, Inc.}

In Schultz v. Boy Scouts of America, Inc., ${ }^{154}$ New Jersey parents sued the Boy Scouts and the Franciscan Brothers in a New York court for the wrongful death of one of their sons and personal injuries to the other. The boys had attended a Boy Scout summer camp in New York State where their New Jersey scoutinaster assaulted thein. The scoutinaster, who was also the boys' teacher in a Franciscan Brothers' school, continued to assault one of the boys in New Jersey that fall, and the boy finally conımitted suicide. The disputed issue in the case was whether New Jersey's charitable imınunity statute should be applied to protect the defendants. Charitable immunity had been judicially abolished in New York. ${ }^{155}$

The court analyzed the weight of contacts according to each state's interest, which in turn depended on the purposes of the laws in con-

153. Lowery, 285 So. $2 \mathrm{~d}$ at 770.

154. 65 N.Y.2d 189,480 N.E.2d 679,491 N.Y.S.2d 90 (1985).

155. Id. at 192, 203, 480 N.E.2d at $681,688,491$ N.Y.S.2d at 92, 99; see also infra note 165 and accompanying text. 
flict. ${ }^{156}$ The court defined the policy dispute as one over loss allocation rather than regulation of conduct. New York's single contact with the dispute, the fact that it was the site of the tortious conduct, did not give New York an interest in applying its loss-allocation law. The significant contacts would have been the presence of New York plaintiffs and possible inedical creditors, ${ }^{157}$ neither of which existed in this case. New Jersey, on the other hand, had numerous siguificant contacts: doinicile of the plaintiffs, the scoutmaster, and one defendant organization, as well as the locus of the relationship between plaintiffs and the charitable orgamizations. These contacts strongly invoked the policy of New Jersey's statute: to encourage the growth of charitable work within its borders. ${ }^{158}$ In addition, the court noted that apphication of the law of common domicile would increase predictability, reduce forum shopping, and encourage inutuality and reciprocity. ${ }^{159}$

Having correctly decided that the law of New Jersey should govern the decision, the Court of Appeals proceeded to confuse the issue. In response to the plaintiffs' public policy exception argument, the court added a public policy argument to its analysis. It noted that the exception should be employed only after application of choice-of-law rules. ${ }^{160}$ Such discussion of public policy was superfluous to the court's analysis, however, since the court had already determined that New York's contacts with the dispute were insufficient to justify application of New York law. ${ }^{161}$ The court never specified what New York's public policy was in this case. The court simply suggested that the policy was reflected in the context of New York's case law abolishing cliaritable immunity. ${ }^{162}$

While New Jersey clearly liad the inore significant interest in this case, ${ }^{163}$ the court's analysis of New York's contacts and policy was nevertheless inadequate. The fact that the conduct occurred in New York was significant. The plaintiffs and defendants purposefully planned tlie New York trip, inaking advance reservations for an extended stay. ${ }^{164}$

156. Schultz, 65 N.Y.2d at 198,480 N.E.2d at $684-85,491$ N.Y.S.2d at $95-96$.

157. Id. at 200,480 N.E.2d at 686,491 N.Y.S.2d at 97 .

158. Id.; Schultz v. Roman Catholic Archdiocese, 95 N.J. 530, 537, 472 A.2d 531, 535 (1984). For further discussion of rationales supporting charitable immunity and New York's reasons for overriding them, see Rakaric v. Croatian Cultural Club, 76 A.D.2d 619, 631-32, 430 N.Y.S.2d 829, 838 (1980).

159. Schultz v. Boy Scouts of America, Inc., 65 N.Y.2d 189, 201, 480 N.E.2d 679, 686-87, 491 N.Y.S.2d 90, 97-98 (1985).

160. Id. at 202,480 N.E.2d at 687,491 N.Y.S.2d at 98 .

161. Id. at 203,480 N.E.2d at $688-89,491$ N.Y.S.2d at $99-100$.

162. Id.

163. See supra text accompanying notes 156-59. The court could also have employed the "common domicile" approach to choose New Jersey law. See, e.g., Neumeier v. Kuehner, 31 N.Y.2d 121, 127-28, 286 N.E.2d 454, 457-58, 335 N.Y.S.2d 64, $69-70$ (1972); see also supra note 88.

164. Schultz v. Boy Scouts of America, 65 N.Y.2d at 209-10, 480 N.E.2d at 693, 491 N.Y.S.2d at 104. 
Consequently, New York was hardly the fortuitous location that often results from an automobile accident on a cross-country trip.

Moreover, while New Jersey's charitable immunity statute may be seen as a loss-allocation statute, the New York case that abohished charitable immumity indicates totally different goals behind the New York law. In that case, the court emphasized the importance of compensating imjured persons and deterring neghigent conduct by charitable organizations. ${ }^{165}$ New York thus had strong imterests in applying its own law barring charitable immumity.

New Jersey's interests, however, were also important. The New Jersey Supreme Court had abolished charitable immunity in 1958 as had the New York Court of Appeals. Within a week, though, the New Jersey legislature passed a law reinstating it. ${ }^{166}$ The speed of that action reflects an intense policy interest. Moreover, the plamtiffs in Schultz had brought suit in New Jersey before filing their claims in New York. The New Jersey Supreme Court dismissed the suit under the New Jersey statute, holding that the statute, passed because of an overriding concern to protect charities economically, unambiguously immunized charitable organizations from the claimed hability. ${ }^{167}$

In this way, analysis of the conflicting imterests of New Jersey and New York considers each state's policy arguments, but ties them to the particular laws in dispute and to the state's contacts with the dispute. ${ }^{168}$ Adding a public policy exception argument to the preceding analysis is redundant and dilutes the focus of the analysis. The court identified no public policy apart from the policy of abolishing charitable immunity, which would already have been evaluated im relation to the New York contacts with the dispute. Agam, no substance was added by this additional layer of analysis.

\section{Wong v. Teimeco, Inc.}

Wong v. Tenneco, Inc. ${ }^{169}$ imvolved a California resident, Lee Wong, who had provided funds and farm equipment to support a Mexican farm1ing operation using a Mexican citizen as a "front man" to hold legal title. Mr. Wong managed the distribution of the farm produce in the United States and paid the Mexican farming operation's expenses fron lis profits. After developing financial difficulties, Mr. Wong entered into a mar-

165. Bing v. Thunig, 2 N.Y.2d 656, 666, 143 N.E.2d 3, 8, 163 N.Y.S.2d 3, 10-11 (1957).

166. This law is currently codified as N.J. STAT. ANN. §§ 2A:53A-7 to -11 (West Supp. 1986);

Schultz v. Roman Catholic Archdiocese, 95 N.J. 530, 536-37, 472 A.2d 531, 534-35 (1984).

167. Id. at $537-38,472 \mathrm{~A} .2 \mathrm{~d}$ at $535-36$.

168. This logic follows the court's own definition of its interest-analysis approach. See supra text accompanying notes $85-86$.

169. 39 Cal. 3d 126, 702 P.2d 570, 216 Cal. Rptr. 412 (1985). 
keting contract with Heggeblade-Marguleas-Tenneco, Inc. (HMT), a California corporation and wholly owned subsidiary of Tenneco. Under this contract, HMT had the exclusive right to market the produce and agreed to remit the proceeds to Wong after commission and expenses. ${ }^{170}$

After several years HMT, at the instigation of the Mexican growers, breached its contract by paying the proceeds directly to the Mexican growers rather than to Wong. Wong sued for the income from the produce sales to which he was entitled under the contract, and for the inarket value of the farn machinery he had supplied but could not now recover. ${ }^{171}$ The jury awarded Wong nearly $\$ 1.7$ inillion but the trial court barred recovery. Under the principle of comity, it found that underlying Wong's contract claim was a significant violation of Mexican law because Mexican law forbade land ownership by foreigners. Under that law the court declared the contract illegal and unenforceable. ${ }^{172}$ After a reversal by the Appellate Division, the California Supreme Court upheld the trial court judgment.

Applying the doctrine of comity, the California Suprene Court declared the applicable law to be that of Mexico, where the cause of action arose. ${ }^{173}$ The court recognized the public policy exception, but found it no violation of California public policy to apply the law of the jurisdiction where the real property was located. ${ }^{174}$ California's customary governmental interest analysis was relegated to a brief footnote written im response to the dissenting opinion. ${ }^{175}$ In that footnote, the court stated that this case presented no true conflict because only Mexico had an interest in regulating real property within its borders. The dissent argued that California maintained a legitimate interest in upholding a California contract between two California residents. ${ }^{176}$ The majority rejected the legitimacy of that imterest since it depended entirely on the violation of Mexican law. Instead, the inajority stated that California's only interest was its public policy against enforcing an illegal contract. ${ }^{177}$

The court's liandling of this case is truly puzzling. The court failed to explain why governmental interest analysis was not applied as the primary analysis of the choice-of-law question. Nor, having relied heavily on them, did the court define the role of comity and public policy doc-

170. Id. at 128-31, 702 P.2d at 571-73, 216 Cal. Rptr. at 413-15; Wong v. Tenneco, Inc., 151 Cal. App. 3d 376, 198 Cal. Rptr. 526, 527 (1984), vacated, 39 Cal. 3d 126, 702 P.2d 570, 216 Cal. Rptr. 412 (1985).

171. Wong, 39 Cal. $3 \mathrm{~d}$ at $132,702 \mathrm{P.2d}$ at 574, 216 Cal. Rptr. at 416.

172. Id. at 133,702 P.2d at 574, 216 Cal. Rptr. at 416 .

173. Id. at 134, $702 \mathrm{P} .2 \mathrm{~d}$ at 575, $216 \mathrm{Cal}$. Rptr. at 417.

174. Id. at 135-36, 702 P.2d at 576-77, 216 Cal. Rptr. at 418-19.

175. Id. at $137 \mathrm{n} .13,702$ P.2d at $577 \mathrm{n} .13,216 \mathrm{Cal}$. Rptr. at $419 \mathrm{n} .13$.

176. Id. at 144, 702 P.2d at 582, 216 Cal. Rptr. at 424 (Mosk, J., dissenting).

177. Id. at 137 n.13, 702 P.2d at 577 n.13, 216 Cal Rptr. at 419 n.13. 
trines in a jurisdiction employing a modern choice-of-law methodology. This is especially troublesome because both lower courts, when applying the comity and public policy doctrines, expressed uncertamty concerning the relationship between these doctrines and governmental interest analysis. ${ }^{178}$

It is also puzzling that the court decided the case by reference to Mexican law even though the lawsuit was for breach of a contract between two California parties, made and to be perforned in California. Mexican law was relevant only because of the Mexican farming operation. Yet the court revived the comity doctrine, prevalent in California before 1960, and cited cases from 1892, 1894, 1913, 1932, and 1941 to support its holding. ${ }^{179}$ Perhaps the court considered Wong's straw-man operation in Mexico in violation of Mexican law so morally offensive as to vitiate all questions of choice of law.

This case provided the court with an excellent opportunity to clarify further its choice-of-law analysis by distinguishing and analyzing a number of factors. First, the court shonld have distinguished the two transactions relevant to the case: (1) the contract sued upon, which mvolved no choice-of-law issue, and (2) the underlying business operation in Mexico. The primary transaction sued upon was the California contract, to which California law was clearly applicable. The court should have emphasized that California law prohibited enforcement of a contract made witl illegal intent. In this way, the foreign law is relevant not as the rule of decision but as datum-namely, evidence establishing the fact of illegality.

Commentators have cliaracterized such use of foreign law as datum as the "incidental question." 180 In his early discussion of governmental interest analysis, Professor Currie indicated that he intended his approach to apply to choice of law only for rules of decision, and not for a law used as datum. ${ }^{181}$ By this distinction, Professor Currie implied that at some future point he would develop a proper conflicts approach specifically for foreign law as datuni. In fact, Professor Currie never did. Later writers note Professor Currie's distinction, but argue that there is

178. Wong v. Tenneco, Inc., 151 Cal. App. 3d 376, 198 Cal. Rptr. 526, 529 (1984), vacated, 39 Cal. 3d 126, 702 P.2d 570, 216 Cal. Rptr 412 (1985); Wong v. Tenneco, Inc., No. 386194, 10 Clerk's Transcript 1798 (Cal. Super. Ct., San Diego County June 1, 1981).

179. Wong, 39 Cal. 3d 126, 134-36, 702 P.2d 570, 575-76, 216 Cal. Rptr 412, 417-18 (1985).

180. R. Cramton, D. CuRrie \& H. KAY, supra note 15, at 393-98; Travelers Ins. Co. v. Workmen's Comp. App. Bd., 68 Cal. 2d 7, 13-14, 434 P.2d 992, 995-96, 64 Cal. Rptr. 440, 443-44 (1967). See generally Kay, Conflict of Laws: Foreign Law as Datum, 53 CALIF. L. Rev. 47 (1965) (in deciding whether to apply foreign law as datum, a court must determine how far the forum should extend the policy of its law); Traynor, Conflict of Laws: Professor Currie's Restrained and Enlightened Forum, 49 CALIF. L. REV. 845, 873-76 (1961) (emphasizing the importance of weighing state interests when foreign law is invoked merely to provide a "datum point").

181. B. CURRIE, supra note 32, at 66-73, 178. 
no reason to subject foreign law as datum to a choice-of-law approach different from that applied to foreign law as rule of decision. ${ }^{182}$ Under sucli reasoning it would have been appropriate for the Wong court to have applied interest analysis to the Mexican law issue.

A better analysis of Wong would have first defined the reach of California law on enforceability of illegal contracts. It could then have proven the illegality of the contract under Mexican law. Finally, the governmental interests would have been analyzed to decide between application of Mexican law and California law.

\section{Enforceability of Illegal Contracts Undcr California Law}

California law declares that a contract made in order to violate the laws of another country sliould not be enforced. ${ }^{183}$ Nevertheless, the question remains whether California intends its law to apply to conduct outside California ${ }^{184}$ if it is illegal where performed but permissible if performed in California. To reach the decision it did, the Wong court should have argued that the issue of the contract's illegality is a policy conceru that the California legislature would have intended its law to reach. ${ }^{185}$

In a previous case the California Supreme Court evaluated the strengtli of the California contacts with the conduct at issue in order to decide whether to extend Califorma law to conduct outside California. ${ }^{186}$ Similarly, California had strong contacts with the illegal conduct at issue in Wong. The contract was planned in California. Both plaintiff and

182. Kay, supra note 180 , at 59; Traynor, supra note 180, at 873-75; see Travelers Insurance Co. v. Workmen's Comp. App. Bd., 68 Cal. 2d 7, 13-14, 434 P.2d 992, 995-96, 64 Cal. Rptr. 440, 443-44 (1967).

183. Wong v. Tenneco, Inc., $39 \mathrm{Cal} .3 \mathrm{~d}$ 126, 135, 702 P.2d 570, 576, $216 \mathrm{Cal}$. Rptr 412, 418 (1985) (quoting 15 S. Williston, A TREATISE ON THE LAW OF CoNTRACTS $\S 1748$, at 121 (3d. ed. 1972)); 6A A. CoRBIN, CoRBIN ON CONTRACTs $\$ 1518$, at 750 (1962); see also Rutkin v. Reinfeld, 229 F.2d 248, 255-56 (2d Cir.), cert. denied, 352 U.S. 844 (1956) (plaintiff could not enforce a claim based on an interest in a Canadian distillery because the purpose of the Canadian venture was to export liquor into the United States in violation of United States law).

184. Kay, supra note 180 , at 61 ("whether or not the foreign law will be permitted to decide the collateral issue by furnishing a datum point depends on how far the forum wishes to cxtend the policy of its own law").

185. Cf. Lewis \& Queen v. N.M. Ball Sons, 48 Cal. 2d 141, 148-51, 308 P.2d 713, 717-19 (1957) (reiterating the importance of deterring illegal bargains).

186. Bernhard v. Harrah's Club, 16 Cal. 3d 313, 546 P.2d 719, 128 Cal. Rptr. 215, cert. denied, 429 U.S. 859 (1976). In Bernhard the California Supreme Court extended liability for negligent conduct to a Nevada resident for its conduct in Nevada on the basis of its strong California contacts. In this case defendant, a Nevada casino, regularly advertised in California in order to attract the business of California residents. California maintained an interest in deterring tavern keepers from encouraging patrons to drink and then drive on California highways. The court reasoned that Nevada tavern keepers who solicited California patrons where "it is reasonably certain these residents will return to California ... in an intoxicated state" directly impinged on this interest. Id. at 322-23, 546 P.2d at 725, 128 Cal. Rptr. at 221. 
defendant sought to reap its benefit in California. California had an articulated interest $m$ deterring parties from intentional subversion of the law. Certainly, parties who planned in California to profit in California from violatimg Mexican law, directly impinged upon California's imterest.

\section{Illegality of the Contract Under Mexican Law}

For California to apply its law against illegal contracts to the parties' conduct in Mexico, a violation of Mexican law must first be estabhished. Since adoption of the 1917 Constitution, ${ }^{187}$ foreign ownership of land without government approval has been illegal in Mexico. In the Wong case, however, the farming business owned no land; the land was held under short-ternı leases. ${ }^{188}$ Furtherniore, Wong, a California citizen, did not hold legal title to any assets. He enforced his infornial arrangement with the Mexican growers by maintaining strict control of the purse strings. ${ }^{189}$ The court identified Wong's control as the illegal act, but cited the Mexican Constitution of 1917, which imposed restrictions only on land ownership, ${ }^{190}$ and Mexico's Foreign Investment Law of $1973,{ }^{191}$ which was not even in effect in 1969 when Wong started his business. ${ }^{192}$

In addition to regnlating land ownership, the Mexican Constitution also provides, "The Nation shall at all times have the right to impose on private property such limitations as the public imterest may demand, ... in order to conserve them and to ensure a more equitable distribution of public wealth." 193 This provision reflects Mexico's strong concerns in preventing foreigners from depleting the country's capital and resources. ${ }^{194}$ Mexico thus protects itself by limitimg foreign control of the economy ${ }^{195}$ and creatimg internal employment-thus reducing Mexico's external dependencies. ${ }^{196}$ Subsequent Mexican laws, executive

187. Wong, 39 Cal. 3d at 129 n.2, 134, 702 P.2d at 571 n.2, 576, 216 Cal. Rptr. at 413 n.2, 417 (quoting Constrrucion art. 27 (Mex.)); Gordon, The Joint Venture as an Institution for Mexican Development: A Legislative History, 1978 ARIz. ST. L.J. 173, 179.

188. 39 Cal. 3d at 130-31, 702 P.2d at 572-73, 216 Cal. Rptr. at 415; Respondents' Petition for Rehearing, Wong v. Tenneco, Inc., No. 386194 (Cal. Super. Ct., San Diego County June 1, 1981), (citing 8 Reporter's Transcript 313-14, 9 Reporter's Transcript 463-74).

189. Wong, 39 Cal. 3d at 131, 702 P.2d at 572-73, 216 Cal. Rptr. at 415.

190. Id. at 128-31, 702 P.2d at 571-73, $216 \mathrm{Cal}$. Rptr. at 413-15.

191. Law for the Promotion of Mexican Investment and Regulation of Foreign Investment (1973) (Mex.).

192. Id. at 129 n.2, 702 P.2d at 571 n.2, 216 Cal. Rptr. at 413 n.2.

193. Gordon, supra note 187 , at 179 (quoting Constrrucion art. 27 (Mex.)).

194. See A. Hoagland, Company Formation in Mexico B-1 (1980); H. Wright, Foreign ENTERPRISE IN MEXICO: LAWS AND PoLICIES 101-02 (1971); Gordon, supra note 187, at 183 (observing that the 1944 decree was a response to the general concern over potential economic dislocation and depletion of resources).

195. A. HoAglAND, supra note 194, at B-1; H. WRIGHT, supra note 194, at 96.

196. A. HoAGLAND, supra note 194, at B-1. 
decrees, and administrative agency actions further reflect this policy. ${ }^{197}$

Following the spirit of this constitutional provision, the 1944 Presidential Decree required permits for any business, including agriculture, with a majority of foreign ownership. ${ }^{198}$ The decree tolerated a purely literal compliance. ${ }^{199}$ As a result, inany foreigners maintained legal title to Mexican businesses or land by means of circuitous devices. ${ }^{200}$ Arguably, Wong effectively owned the business through his financial control, thus violating the decree's broader policy aims. In literal terms, however, Wong did not violate the decree because legal title was held by his Mexican "associate."

The 1973 Foreign Investınent Law extended regulation to all Mexican entities "in which foreigners in any manner exercise control of policies and management of the entity."201 The law generally had no retroactive effect ${ }^{202}$ and required only that foreign-controlled businesses register with the National Foreign Investment Commission (FIC). ${ }^{203}$ Wong's failure to register with the FIC, as a foreigner controlling the inanagement of a Mexican business, was probably his only violation of the 1973 Act (and thus of Mexican law). To inost California courts, this infraction would be no more serious than a contractor's failure to obtain a building permit in California. California courts have held that such technical failures often do not justify voiding the contract, particularly when the resulting forfeiture would be unreasonably harsh. ${ }^{204}$ For Wong, the voiding of his contract under California law was indeed a harsh resnlt. At trial both sides stipulated that Wong would not have been able to enforce his agreement in Mexico. ${ }^{205}$ This stipulation, however, inay have resulted more from a realistic assessinent of the ad hoc power of administrative agencies ${ }^{206}$ than from any actual violation of

197. Id. at B-1 to -4 (reviewing the history of Mexico's controls over foreign investment).

198. Decree of June 29, 1944, D.O., July 7, 1944; H. WR1GHT, supra note 194, at 101-03; Gordon, supra note 187, at 183-84.

199. U.S. DeP'T OF COMMERCE, INVESTMENT IN MeXico $18-19$ (1955).

200. H. WRIGHT, supra note 194, at 116-18; Vizcaino, The Law on Foreign Investment, 7 GA. J. INT'L AND COMP. L. 33, 36 (1977).

201. Trevino, New Rules Affecting Foreign Investment in Mexico - The 1973 Law on Foreign Investments, in Doing Business IN MEXico 27 (E. Newberger ed. 1974); see Law for the Promotion of Mexican Investment and Regulation of Foreign Investment art. 5 (1973) (Mex.); see also A. Hoagland, supra note 194, at B-11; Doing Business in Mexico, A Price Waterhouse INFormation Guide 24 (1977) (hereinafter cited as Price Waterhouse); Gordon, supra note 187 , at 200.

202. Price Waterhouse, supra note 201, at 23; Gordon, supra note 187, at 202; Trevino, supra note 201, at 26.

203. Trevino, supra note 201, at 30.

204. M. Arthur Gensler, Jr. \& Assocs., Inc. v. Larry Barrett, Inc., 7 Cal. 3d 695, 702-03, 499 P.2d 503, 508, 103 Cal. Rptr. 247, 252 (1972); Lewis \& Queen v. N.M. Ball Sons, 48 Cal. 2d 141, 151, 308 P.2d 713, 719 (1957).

205. Wong, 39 Cal. $3 d$ at 133 n.8, 702 P.2d at 575 n.8, 216 Cal. Rptr. at 417 n.8.

206. See Gordon, supra note 187 , at 188. 
Mexican law.

\section{Governmental Interest Analysis to Determine Choice of Law}

If the court had determined that Wong violated Mexican law sufficiently to render his contract with HMT void, the court should then have used governmental interest analysis rather than the principle of comity to determine whether to apply the Mexican law. In terms of Califorma's interest in upholding the reasonable expectations of California parties to a valid California contract, ${ }^{207}$ Califorina law should have served as the rule of decision in the case. But Califorina also had an interest in deterring subversion of the law. ${ }^{208}$ If the court had found the contract illegal, the court could have held, as a matter of California law, that the contract was unenforceable.

The imcidental question arises in deciding whether California or Mexican law should determine the "illegality" of the contract. ${ }^{209}$ Applying governmental interest analysis, the Wong court should have held that while California had a policy allowing anyone to own land or conduct business, California had no interest in applying its policy in this situation because the scope of that policy is limited to lands or businesses located in California. In contrast, Mexico liad repeatedly demonstrated a determination to control busmess assets within its borders. ${ }^{210}$ The court should have noted that domestic control of land and business has been a inajor tenet of every Mexican law involving foreign investment since 1917. Administrative agencies lave made exceptions to this policy, but insist on maintaining control and the right to refuse exceptions. ${ }^{211}$ Mexico thus had a strong and repeatedly expressed interest in any foreign business operation carried out in Mexico.

Thus the Wong court could liave used the modern doctrine of interest analysis to arrive at exactly the saine result it reached by way of comity. Had the court followed this approach, it would have been able to distinguisl clearly between foreign law as rule of decision and foreign law as datum. It would also have been able to define exactly what governmental interests were involved in each. Because the public policy exception lacks this focus, the court ouly confused the issue by sug-

207. Cf. Bernkrant v. Fowler, 55 Cal. 2d 588, 594-95, 360 P.2d 906, 909, 12 Cal. Rptr. 266, 269 (1961).

208. See supra notes $183-86$ and accompanying text.

209. See supra text accompanying notes 180-82.

210. See supra notes $193-97$ and accompanying text.

211. See, e.g., A. HOAGLAND, supra note 194, at B-6, B-13 (discussing registration requirements under the 1973 Foreign Investment Law, and circumstances under which the Foreign Investment Commmission sometimes grants discretionary exceptions to the statutory requirements of Mexican ownership); Gordon, supra note 187, at 187-201 (discussing the role of the executive in enforcing Mexicanization and granting exceptions since World War II). 
gesting that in certain situations governmental interest analysis should be subordinated to the older doctrines. With the availability of proper choice-of-law analysis, the court had no need for the coinity and public policy doctrines at all. Both lower courts in this case had indicated an uncertainty as to how comity and the public policy exception should interact with governinental interest analysis. ${ }^{212}$ The California Supreine Court, in relegating governmental interest analysis to a footnote, not only lost this opportunity to give guidance to lower courts but further coinpounded the confusion.

\section{CONCLUSION}

The shortcomings of traditional lex loci rules have been clear for many years. Vested rights erred by being too precise. Comity and public policy erred at the opposite extreme, by being catch-alls without analytical focus. The evolution of modern choice-of-law techniques reflects an effort to develop a clear, principled basis for analyzing what was previously termed simply "public pohicy." Modern approaches attempt to consider policy issues more analytically by focusing on the direct relationship of the policy issue to the specific contacts and laws in the case, rather than on arbitrary factors that inay produce fortuitous and inequitable results.

These modern analytical tools have created uncertainty and unpredictability beyond that which occurred in the use of the old, rigid choiceof-law rules. They have been criticized for their potential to encourage forum shopping and excessive hitigation. Although these criticisms may be valid, even the strongest critics do not suggest a return to old, arbitrary rules. The modern approaches are generally viewed as a necessary development to free the judicial system froin the increasingly obvious inappropriateness of the old rules.

With the advent of approaches which evaluate the policies of the laws in dispute, the doctrines of comity and public policy no longer play a significant role. The Boardman and Schultz cases, in reviving the concept of public policy, have confused this issue. Wong has exacerbated the confusion by putting in question the California Supreme Court's chosen approach for deciding choice-of-law issues. Courts deciding these cases have not done choice-of-law analysis a service by reviving the old doctrines. They could better have used this opportunity to state clearly that comity and public policy argunnents should no longer be used as choiceof-law rules in any state with a pohicy-oriented approach. Instead, the

212. See supra note 178 and accompanying text. 
modern approach not only encompasses all relevant policy concerns, but focuses them within an analytical framework.

Holly Sprague*

* B.A. 1962, Ohio Wesleyan University; M.A. 1969, University of Rochester; third-year student, Boalt Hall School of Law, University of California, Berkeley. 
